\title{
CONDITIONAL MODEL OF REAL ESTATE VALUATION FOR LAND LOCATED IN DIFFERENT LAND USE ZONES
}

\author{
Agnieszka Bieda, PhD \\ AGH University of Science and Technology \\ Department of Geomatics \\ e-mail: agnieszka.bieda@agh.edu.pl
}

\begin{abstract}
Real estate valuation is carried out correctly if it takes into account all the conditions occurring on a given market at the time of its performance. One of the important determinants of correct valuation is the proper determination of the land use class of the property being valued. It is equally important to find similar properties with the same land use classes as the property subjected to valuation. This does not pose a problem when a property is located within an area with one specific land use zone. If, however, its land use zoning is not homogeneous, finding similar properties may be difficult.

If those contained in the database of comparable properties differ from the real estate being valued with regard to land uses of individual areas or proportions of areas with a specific use, it is suggested to divide transaction prices obtained for the whole property into components of those prices that correspond to the fragments of this property with specific land uses. In this paper, the conditional model has been used for this purpose.
\end{abstract}

Key words: conditional model, areas of different land uses, land use of the property, real estate valuation.

JEL Classification: C19, R14.

Citation: Bieda A., 2018, Conditional Model of Real Estate Valuation for Land Located in Different Land Use Zones, Real Estate Management and Valuation, vol. 26, no. 1, pp. 122-130.

DOI: $10.2478 /$ remav-2018-0010

\section{Introduction}

For each property valuation, it is important for the obtained value to reflect market conditions existing at the time of valuation. Although real estate valuation methods depend on the experience of individual countries, their vast majority relies on some form of comparison of the real estate being valued with other properties (PAGOURTZI et al. 2003).

Polish regulations on real estate valuation (АСТ 1997) require such a comparison to be made based on so-called "similar properties". This term covers real estate that is comparable to the property subjected to the valuation procedure as far as its location, legal status, land use, intended purpose, as well as other attributes that affect its value are concerned. The listed attributes can be divided into two groups (ZYGA 2012). The first one includes attributes that define similarity of the objects contained in the real estate database to the property being valued, such as legal status, land use or intended purpose. The second one includes attributes such as the location, surroundings, accessibility, or shape of the parcel, based on which the level of transaction prices is adjusted to determine the market value of the property subjected to the valuation procedure. All these attributes should be taken into account when preparing individual real estate valuations (CELLMER et al. 2014). This task, however, is hindered by the complexity and non-homogeneity of real properties (DAWIDOWICZ et al. 2004) as well as by the diversity and imprecision of the attributes (RENIGIER-BIŁOZOR et al. 2017). 
A variety of determinants of spatial planning (АCT 2003) significantly influence the potential use of a property for specific purposes (KALUS, HABDAS 2012) and, consequently, its value. Therefore, statutory recommendation for a valued property to be compared to properties with similar land uses was established. Unfortunately, characteristics of the planning space which shape the records of spatial planning documents frequently lead to the establishment of lines that delimit areas with different land uses, whose configuration is not quite consistent with the course of cadastral boundaries. Although these lines should extend along the boundaries of land properties (BIEDA et al. 2012), this is not always possible because of the existing land development (ADAMCZYK et al. 2014). As a result, surveyors frequently have to deal with real estate located in different land use zones.

Valuation of real estate with different land uses should be performed in the same way as any other. However, it is necessary to find similar properties which consist of areas with the same land uses, and in the same proportions, as the real estate being valued; this, however, can be difficult on the local market. According to the author, misdetermination of the land use (ADAMCZYK, BIEDA 2014) may also result in the erroneous definition of property value. Hence, the idea to specify total transaction prices of comparable properties and the unit values of the areas of specific land use. This process is feasible, for example, by using a variety of mathematical models that belong to the statistical analysis of the market in comparative approach.

If the configuration of different land use zones in a single parcel is very complicated, finding even a few properties similar to the one being valued, which would be the objects of transactions in the real estate market can be considered a success. If, however, it is necessary to divide transaction prices according to the areas of specific land uses, this can be carried out by applying a conditional model that has long been used in surveying to adjust observation results (CZAJA 1997), (PREWEDA 2013) and (WIŚNIEWSKI 2005). In real estate valuation, it has already proven to be useful for separating: the value of land from the value of buildings in the valuation of built-up properties (PARZYCH 2009b), land use zones during the valuation of agricultural real estate (BYDŁOSZ et al. 2011), (PARZYCH 2008) and (PARZYCH 2009b), as well as forest site types when valuating forest real estate (PARZYCH 2008), (PARZYCH 2009a) and (PARZYCH 2009b). It was also proposed for use in general assessment (PARZYCH, BYDEOSZ 2008).

This model is based on the analysis of transaction prices for the entire property. It is used when the number of transactions involving properties with non-homogenous land use on a given market is smaller than the number of analyzed components of the property. Good results are dependent on the determination of approximate unit values of the prices of specific components of real estate, according to the situation in the analyzed real estate market.

\section{Methodology of property valuation using the conditional model}

In order to separate the transaction price of a land property which is covered by different land use zones into price components corresponding to fragments with a specified land use, the equations in Form (1) should be built as follows:

$$
C_{T j}=S_{1} \cdot\left(\tilde{c}_{1}+\delta_{1}\right)+S_{2} \cdot\left(\tilde{c}_{2}+\delta_{2}\right)+\cdots+S_{i} \cdot\left(\tilde{c}_{i}+\delta_{i}\right)
$$

where:

$C_{T j} \quad$ - transaction price of the entire $j$-th property,

$S_{i} \quad$ - surface area of the area covered by a specified land use class, as the $i$-th element of the $j$-th property,

$\tilde{c}_{i} \quad$ - approximate unit value of the $i$-th component of the property,

$\delta_{i} \quad$ - random deviation to the approximate unit value of the $i$-th component of the property.

After multiplying the corresponding terms in Equation (1) and grouping them, a conditional model of real estate unit prices is obtained, which is expressed as in Formula (2).

$$
S_{1} \cdot \delta_{1}+S_{2} \cdot \delta_{2}+\cdots+S_{i} \cdot \delta_{i}=C_{T j}-S_{1} \cdot \tilde{c}_{1}-S_{2} \cdot \tilde{c}_{2}-\cdots-S_{i} \cdot \tilde{c}_{i}
$$

In the equation (2), the intercept is the difference between the transaction price $\left(C_{T j}\right)$ for the property and the model price $\left(C_{M j}\right)$, which is the approximate price for a given property. The formula for the model price can be written as (3).

$$
C_{M j}=S_{1} \cdot \tilde{c}_{1}+S_{2} \cdot \tilde{c}_{2}+\cdots+S_{i} \cdot \tilde{c}_{i}
$$


For specifying the approximate value, unit values of real estate located in the same land use zone which were objects of trade on the local real estate market can be used. Hence, the value of the intercept $\left(\Delta C_{T j}\right)$ of the equation (2) can be determined using the values defined by Formula (4).

$$
\Delta C_{T j}=C_{T j}-S_{1} \cdot \tilde{c}_{1}-S_{2} \cdot \tilde{c}_{2}-\cdots-S_{i} \cdot \tilde{c}_{i}=C_{T j}-C_{M}
$$

After substituting the intercept in Equation (2) with the denotation adopted in Formula (4), the conditional model for unit real estate values will take the following form (5).

$$
S_{1} \cdot \delta_{1}+S_{2} \cdot \delta_{2}+\cdots+S_{i} \cdot \delta_{i}=\Delta C_{T j}
$$
(6).

For several similar properties, a system of equations can be built symbolically in the matrix form

$$
\{S\} \cdot\{\delta\}=\{\Delta C\}
$$

where:

$\{S\} \quad$ - matrix formed from values of surface areas of the individual components of a property,

$\{\delta\}-$ random deviation vector for model unit values of real estate components,

$\{\Delta C\} \quad$ - matrix formed from the differences between transaction prices $\left(C_{T j}\right)$ and approximate values for the analyzed properties $\left(C_{M j}\right)$.

The system of equations (6) satisfies the Gauss-Markov assumptions described by Formula (7).

$$
E[\{S\} \cdot\{\delta\}]=\{0\} \Rightarrow E[\delta]=0
$$

The estimator of the random deviation vector $(\hat{\delta})$ can be calculated using Formula (8).

$$
\{\hat{\delta}\}=\{S\}^{T} \cdot\left(\{S\} \cdot\{S\}^{T}\right)^{-1} \cdot\{\Delta C\}
$$

Unit values of the real estate components $\left(\hat{c}_{i}\right)$ can be calculated from Formula (9).

$$
\hat{c}_{i}=\tilde{c}_{i}+\delta_{i}
$$

Estimators of residual variance $\left(\hat{\sigma}_{0}^{2}\right)$ are expressed using Formula (10).

$$
\hat{\sigma}_{0}^{2}=\frac{\{\widehat{\delta}\}^{T} \cdot\{\widehat{\delta}\}}{j}
$$

It is necessary to determine the covariance matrix $(\operatorname{Cov}\{\hat{\delta}\})$ of random deviations, which is calculated from Formula (11).

$$
\operatorname{Cov}\{\hat{\delta}\}=\hat{\sigma}_{0}^{2} \cdot\left(\{S\}^{T} \cdot\left(\{S\} \cdot\{S\}^{T}\right)^{-1} \cdot\{S\}\right)
$$

Equation (12) can be written for the covariance matrix of the vector of unit values of real estate components.

$$
\operatorname{Cov}\{\hat{c}\}=\hat{\sigma}_{0}^{2} \cdot\left(\{I\}-\{S\}^{T} \cdot\left(\{S\} \cdot\{S\}^{T}\right)^{-1} \cdot\{S\}\right)
$$

The value of the property subjected to valuation $(\widehat{W})$ is determined using Formula (13).

$$
\widehat{W}=S_{1} \cdot \hat{c}_{1}+S_{2} \cdot \hat{c}_{2}+\cdots+S_{i} \cdot \hat{c}_{i}
$$

The inaccuracy of the determined property value is estimated using Formula (14).

$$
\sigma(\widehat{W})=\sqrt{\left\{S_{W}\right\} \cdot \operatorname{Cov}\{\hat{c}\} \cdot\left\{S_{W}\right\}^{T}}
$$

where:

$\left\{S_{W}\right\}$ - vector of surface areas of the components of the real estate being valued.

Performance of the calculations according to the scheme presented above is valid only if all similar properties are defined by attributes identical to the ones used in the property being valued.

\section{Exemplary valuation of land property covered by different land use zones}

In order to verify the suitability of the conditional model for the valuation of land properties covered by different land use zones, the value of a land property located in one of Krakow's housing estates was estimated. The property being valued consisted of one plot of $3,780 \mathrm{~m}^{2}$ and was located in areas 
which, in the local zoning plan, were intended for multi-family housing (MW), commercial and public development $(\mathrm{U})$, public roads $(\mathrm{KD})$ and public green spaces $(\mathrm{ZP})$.

The data necessary for the valuation of the subject real estate were acquired from the Registry of Property Prices and Values (REGISTER 2016). They formed the basis for the creation of a database of similar properties, which is presented in Table 1.

Table 1

Database of properties similar to the one being valued

\begin{tabular}{cccc}
\hline No. & $\begin{array}{c}\text { Surface area of properties } \\
{\left[\mathbf{m}^{2}\right]}\end{array}$ & $\begin{array}{c}\text { Transaction price of } \\
\text { properties [PLN] }\end{array}$ & $\begin{array}{c}\text { Unit price } \\
{\left[\mathbf{P L N} / \mathbf{m}^{\mathbf{2}}\right]}\end{array}$ \\
\hline 1 & 3300 & 400000 & 121 \\
\hline 2 & 4980 & 1100000 & 221 \\
\hline 3 & 2880 & 576000 & 200 \\
\hline$W$ & 3788 & $?$ & $?$ \\
\hline
\end{tabular}

Source: Own study.

The properties introduced to the real estate database were objects of real estate transactions in the years 2013-2014, at a time when prices in Krakow were stable (BIEDA 2017). Their location, surroundings, shape, and access could be described with the same values of attributes. All the properties selected for valuation had the same land use class in the local zoning plan as the property being valued. The only differences were the proportions of the surface areas of various land uses. These surface areas were calculated on the maps and are presented in Table 2.

Table 2

Surface areas of different land uses $\left[\mathrm{m}^{2}\right]$

\begin{tabular}{cccccc}
\hline No. & MW & KD & ZP & U & Total \\
\hline 1 & 300 & 250 & 2340 & 410 & 3300 \\
\hline 2 & 1550 & 800 & 1680 & 950 & 4980 \\
\hline 3 & 720 & 550 & 1100 & 510 & 2880 \\
\hline W & 1250 & 430 & 880 & 1220 & 3788 \\
\hline
\end{tabular}

Source: Own study.

The information contained in Table 2 allowed for constructing a matrix, which was used to define the unit values of real estate located in the following land use zones: MW, KD, ZP and U (15).

$$
S=\left[\begin{array}{cccc}
300 & 250 & 2340 & 410 \\
1550 & 800 & 1680 & 950 \\
720 & 550 & 1100 & 510
\end{array}\right] \quad\left[\mathrm{m}^{2}\right]
$$

In order to determine approximate values of the areas of specific land uses, transaction prices of the properties with homogeneous land use zones were analyzed. These properties were sold on the same local market and in the same period as the properties contained in the comparable database (Table 3).

Table 3

Characteristics of the sets which approximate values come from ( $\tilde{c})$

\begin{tabular}{|c|c|c|c|}
\hline Intended use & $\begin{array}{l}\text { Number of } \\
\text { transactions }\end{array}$ & $\begin{array}{c}\text { Average transaction } \\
\text { price }\left[\mathrm{PLN} / \mathrm{m}^{2}\right]\end{array}$ & $\begin{array}{c}\text { Standard deviation } \\
{\left[\mathrm{PLN} / \mathrm{m}^{2}\right]}\end{array}$ \\
\hline MW & 12 & 403 & 16 \\
\hline KD & 7 & 142 & 3 \\
\hline $\mathrm{ZP}$ & 5 & 56 & 2 \\
\hline $\mathrm{U}$ & 9 & 298 & 9 \\
\hline
\end{tabular}

Source: Own study.

Further in the calculations, only the average values of the transaction prices obtained for properties with a specific intended use were used. Their falsity can be specified from weights 
determined from standard deviations. In this case, however, the scatter of the bases was small (below $5 \%)$ and, therefore, the weights were not included in the calculations.

Values defined as the arithmetic means of all recorded transactions were included in the matrix of approximate values (16).

$$
\tilde{c}=\left[\begin{array}{c}
403 \\
142 \\
57 \\
298
\end{array}\right] \quad\left[\mathrm{PLN} / \mathrm{m}^{2}\right]
$$

Based on the matrix $\{S\}$ and the matrix of approximate prices $\{\tilde{c}\}$, model prices for individual properties $\left(C_{M j}\right)$ and price increments $\left(\Delta C_{T j}\right)$ were determined, from which the matrix of the intercept (17) was built.

$$
\Delta C=\left[\begin{array}{c}
-9620 \\
-15430 \\
-5840
\end{array}\right] \quad[\mathrm{PLN}]
$$

After solving Equation (6), deviations $\left(\hat{\delta}_{i}\right)$ to the approximate unit values of the corresponding components of the property were obtained (18).

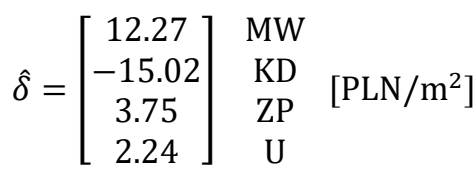

Based on the determined deviations $\left(\hat{\delta}_{i}\right)$ and the approximate unit values $\left(\tilde{c}_{i}\right)$, the values $\left(\hat{c}_{i}\right)$ of the specific areas were determined (19).

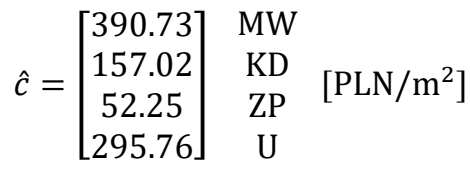

The residual variance $\left(\hat{\sigma}_{0}^{2}\right)$ for the applied model amounted to 131.80 PLN2 ( $\hat{\sigma}_{0}=11.48$ PLN). On this basis, covariance matrices were determined: of random deviations (20) and of the unit values of specific components of the property (21).

$$
\begin{aligned}
\operatorname{Cov}(\hat{\delta}) & =\left[\begin{array}{cccc}
114.5534 & -8.7186 & -4.4539 & 43.3534 \\
-8.7186 & 127.3894 & -2.2519 & 21.9195 \\
-4.4539 & -2.2519 & 130.6472 & 11.1974 \\
43.3534 & 21.9195 & 11.1974 & 22.8026
\end{array}\right] \quad\left[\mathrm{PLN} / \mathrm{m}^{2}\right]^{2} \\
\operatorname{Cov}(\hat{c}) & =\left[\begin{array}{cccc}
17.2441 & 8.7186 & 4.4539 & -43.3534 \\
8.7186 & 4.4081 & 2.2519 & -21.9195 \\
4.4539 & 2.2519 & 1.1504 & -11.1974 \\
-43.3534 & -21.9195 & -11.1974 & 108.9949
\end{array}\right] \quad\left[\mathrm{PLN} / \mathrm{m}^{2}\right]^{2}
\end{aligned}
$$

Based on the covariance matrix of random deviations, their standard deviations $(\sigma(\hat{\delta}))$ from approximate unit values were determined (22).

$$
\sigma(\hat{\delta})=\left[\begin{array}{c}
10.70 \\
11.29 \\
11.43 \\
4.78
\end{array}\right] \begin{array}{cc}
\mathrm{MW} & \\
\mathrm{ZP} & {\left[\mathrm{PLN} / \mathrm{m}^{2}\right]}
\end{array}
$$

The covariance matrix of unit values of specific components of the property was used to determine the standard deviations $(\sigma(\hat{c}))$ of unit values of the individual land use zones (23).

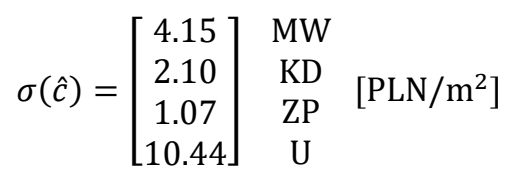

Using the prices of the individual land use zones determined with the conditional model, the value of the property was determined. The final result obtained by Formula (13) was $\widehat{W}=962,736$ PLN. 
Standard deviation $\sigma(\widehat{W})=5,699$ PLN, which accounts for approx. $0.6 \%$ of the determined market value.

\section{Validity of valuation with specifying different land use zones}

The unit value of the real estate subjected to the valuation procedure, calculated from the conditional model, was PLN 255/ $\mathrm{m}^{2}$. Thus, it did not fall within the range between the lowest and highest transaction prices from the database of comparable properties, which were $121 \mathrm{PLN} / \mathrm{m}^{2}$ and 221 $\mathrm{PLN} / \mathrm{m}^{2}$, respectively. This does not necessarily mean, however, that the value obtained in the conditional model was completely useless.

The value obtained in the conditional model was compared with the arithmetic mean of unit transaction prices from the database of comparable properties, i.e. $181 \mathrm{PLN} / \mathrm{m}^{2}$. It was determined with the standard deviation of $42.92 \mathrm{PLN} / \mathrm{m}^{2}$ and multiplied by the surface areas of individual areas (Table 4).

Table 4

Comparison of values obtained in conditional model with values obtained from arithmetic mean of unit transaction prices from database of comparable properties

\begin{tabular}{ccccccc}
\hline \multirow{2}{*}{ No. } & Calculation method & MW & KD & ZP & U & Total \\
\hline \multirow{2}{*}{1} & conditional model & 117219 & 39256 & 122265 & 121260 & 400000 \\
\cline { 2 - 7 } & average unit price & 54210 & 45175 & 422835 & 74086 & 596305 \\
\hline \multirow{2}{*}{2} & conditional model & 605632 & 125620 & 87780 & 280968 & 1100000 \\
\cline { 2 - 7 } & average unit price & 280083 & 144559 & 303574 & 171664 & 899879 \\
\hline \multirow{2}{*}{3} & conditional model & 281326 & 86364 & 57475 & 150836 & 576000 \\
\cline { 2 - 7 } & average unit price & 130103 & 99384 & 198768 & 92156 & 520412 \\
\hline \multirow{2}{*}{ W } & conditional model & 488413 & 67521 & 45980 & 360822 & 962736 \\
\cline { 2 - 7 } & average unit price & 225873 & 77700 & 159015 & 220452 & 683041 \\
\hline
\end{tabular}

Source: Own study.

Differences in the obtained values are clearly noticeable. For properties from the comparable database, the values determined from the unit transaction price were, respectively, $50 \%$ higher, and $18 \%$ and $10 \%$ lower, whereas for the property being valued - $29 \%$ higher than the value obtained in the conditional model. Of course, these discrepancies resulted from the different proportions of areas of different land uses. Figure 1 demonstrates the contribution of the values of individual land use zones to the total value of the parcels.

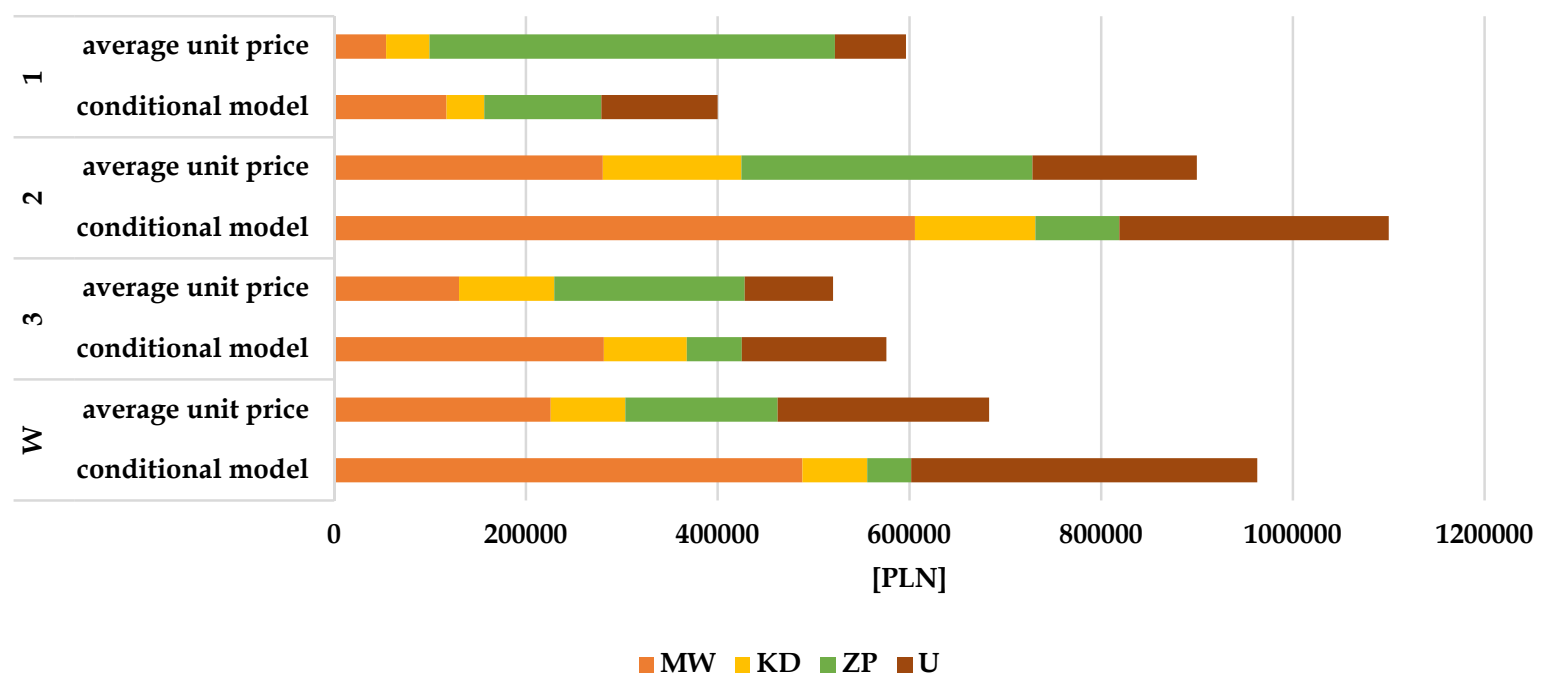

Fig. 1. Contribution of the values of individual land use zones to the total value of the real estate.

Source: Own study. 
Averaging the prices in all land use zones not only changed the value of the entire land but, above all, the values of the individual zones. The smallest differences were noticeable in the case of areas where the unit value obtained from the conditional model was closest to the arithmetic mean unit price, i.e. for public roads (KD). The difference between them was only $-24 \mathrm{PLN} / \mathrm{m}^{2}$, which translates into approx. $-16 \%$. For the remaining areas, there were clear discrepancies, such as $54 \%$ for $\mathrm{MW},-246 \%$ for $\mathrm{ZP}$, and $39 \%$ for $\mathrm{U}$. They resulted from much greater differences between the results of the applied calculation methods.

The arithmetic mean, however, does not account for the fact that the proportions of surface areas of individual land use zones are different for the whole property (Figure 2).

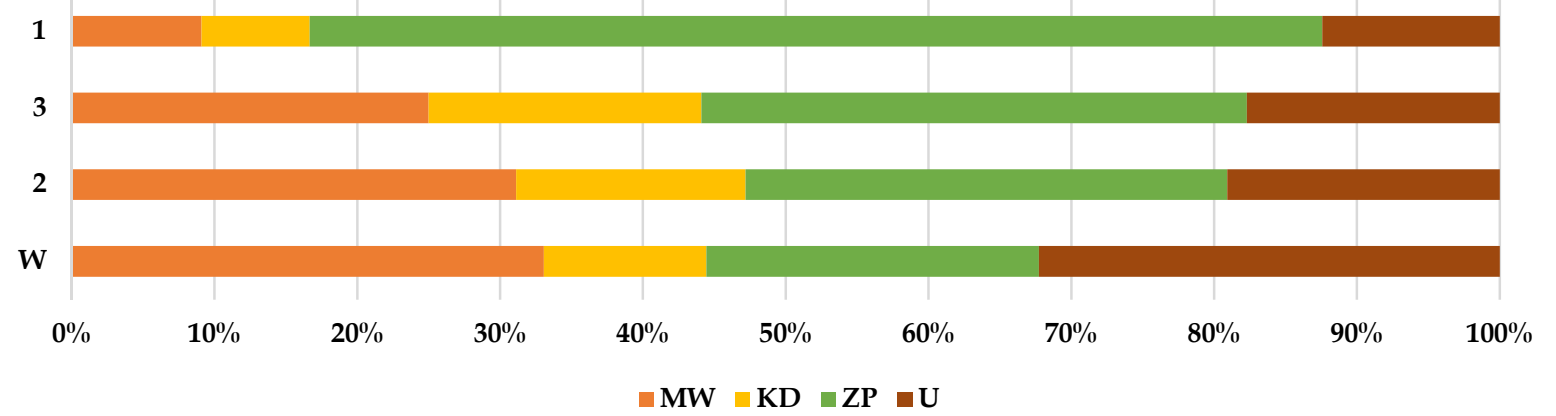

Fig. 2. Proportion of surface areas of individual land use zones in the surface area of the entire property. Source: Own study.

Properties No. 2 and 3 consisted of different land use zones, the surface areas of which had similar proportions. Unfortunately, property No. 1 differed greatly in this respect. Its buyer paid mainly for areas intended for public green spaces (ZP) and public roads (KD), which were completely useless. The total share of these areas in the entire surface area of the parcel was about $80 \%$, while in properties No. 2 and 3 - it was much smaller (about 50\%). That is why the unit price of that property was much lower than the rest, and affected the final value of the property being valued.

On the other hand, the total surface area of Zones ZP and KD in the valued property was the smallest and amounted to approx. 40\%. A large share of expensive areas intended for development (i.e. MW and $U$ ) resulted in a significant increase in the unit value specified in the conditional model.

\section{Conclusions}

Along with the development of an economic society, a need arises to develop a reliable and effective approach to determining the market value of real estate (CHEN et al. 2017). It is frequently the case that a common arithmetic mean of transaction prices is closer to rational valuation than a complex model (ADAMCZEWSKI 2006). However, with properties located in different land use zones, this rule does not always apply. It is clearly noticeable in the presented example that lack of homogeneity in land use classes can be problematic if the database of comparable properties contains real estate with various proportions of different land use zones and, additionally, they are dissimilar to the property being valued.

Calculation algorithms of the methods which assume that it is enough if land use classes of the real estate in the database of comparable properties are similar to the land use classes of the property being valued, and do not take into account the possible differences in proportions of different land use zones, should not be used for the valuation of properties located in non-homogeneous areas, unless the database contains real estate whose areas of individual land use zones are similar to the areas of these land use zones in the property being valued.

If, however, it is not possible to establish a comparable database containing real estate with the same proportions of land use zones as the property being valued, the author suggests using algorithms allowing for the division of transaction prices into components corresponding to the areas of specific land use zones.

One such method is valuation using the conditional model, as presented in this paper. Its obvious advantage is that there is no need to build a large database to carry out calculations. However, due to the fact that it is based on the method of least squares, it should be remembered that it may not be resistant to outliers (LIGAS 2010). One discrepant observation is enough to completely disturb the 
estimation results. It is particularly important to bear this in mind when there are only a few properties in the comparable database.

However, in order to state unambiguously whether this valuation methodology may, or perhaps even should be introduced for wider use, further analyses are required to be conducted in various markets, and for real estate with a subdivision into different land use zones.

\section{References}

ADAMCZEWSKI Z., 2006, Elementy modelowania matematycznego w wycenie nieruchomości. Podejście porównawcze (Elements of Mathematical Modelling in Real Estate Valuation. Comparative Approach), Oficyna Wydawnicza Politechniki Warszawskiej, Warszawa.

AdAmczyK T., Begović V., Bieda A., Bielecka E., Bugaj P., DaWidowicz A., DŽunić I., Gajos M., JANKOWSKA M., KereKović D., KRUKOWSKA K., KrysZK H., KurOWSKA K., PARZYCH P., RAHMONOV O., SCHRUNK I., WÓJCIAK E., ŹRÓBEK R., 2014, Spatial Data in Wide Geospace, Nacionalna knjižnica, Zagreb.

ADAMCZYK, T., BIEDA, A, 2014, Intended Use of Real Estate as a Time Changeable Attribute for Determining Compensation for Nationalized and Expropriated Lands, Real Estate Management and Valuation, Vol. 22, No. 4, pp. 35-50.

BIEDA, A., 2017, Urban Renewal and the Value of Real Properties, Studia Regionalne i Lokalne, No. 3(69), pp. 5-28.

BIEDA A., HANUS P., HYCNER R, 2012, Geodezyjne aspekty planowania przestrzennego $i$ wybranych opracowań projektowych (Surveying Aspects of Land Use Planning and Selected Design Studies), Wydawnictwo Gall, Katowice.

BydŁosz, J., PARZYCH, P., DĄBrowsKi, J., 2011, The Possibilities of Real Estates Market Development in Poland in Connection with INSPIRE Directive, Geomatics and Environmental Engineering, Vol. 5, No. 1 , pp. 15-23.

Cellmer, R., BeŁeJ, M., ŹRóbeK, S., Kovac, M., S., 2014, Urban Land Value Maps - a Methodological Approach, Geodetski vestnik, Vol. 58, No. 3, pp. 535-551.

CHen, Z., Hu, Y., ZHANG, C. J., LiU, Y., 2017, An Optimal Rubrics-Based Approach to Real Estate Appraisal, Sustainability, Vol. 9, No. 6, pp. 1-19.

CZAJA, J., 1997, Modele statystyczne w informacji o terenie (Statistical Models in Land Information), Wydawnictwo Akademii Górniczo-Hutniczej, Kraków.

DAWIDOWICZ, A., RADZEWICZ, A., RENigIER-BIŁOZOR, M., 2014, Algorithm for Purposes of Determining Real Estate Markets Efficiency with Help of Land Administration System, Survey review, No. 46(336), pp. 189-204.

KALUS S., HABDAS M., 2012, Ustawa o planowaniu $i$ zagospodarowaniu przestrzennym jako instrument kształtowania wartości rynkowej nieruchomości (The Act on Spatial Planning and Management and its Influence on the Market Value of Immovables), Studia Iuridica Agraria, T. 10, pp. 76-91.

LiGAS M., 2010, Metody statystyczne w wycenie nieruchomości (Statistical Methods in Real Estate Valuation), Studia i Materiały Towarzystwa Naukowego Nieruchomości, Vol. 18, No. 1, pp. 49-64.

PARZYCH P., 2008, Warunkowe modele estymacji jednostkowych cen elementów nieruchomości (The Conditional Estimation Models for Unit Estates' Elements), Studia i Materiały Towarzystwa Naukowego Nieruchomości, Vol. 16, No. 2, pp. 93-100.

PARZYCH, P., 2009a, Warunkowy model estymacji jednostkowych cen dla nieruchomości leśnych (The Conditional Model of Unit Price Estimation for Forest Estates), Studia i Materiały Towarzystwa Naukowego Nieruchomości, Vol. 17, No. 1, pp. 47-57.

PARZYCH P., 2009b, Modele estymacji wartości rynkowej lub katastralnej nieruchomości zurbanizowanych, rolnych $i$ leśnych (Estimation Models of the Market of Cadastral Value of Urbanized, Agricultural and Forest Estates), AGH Uczelniane Wydawnictwa Naukowo-Dydaktyczne, Kraków.

PARZYCH, P., BYDŁOSZ, J., 2008, Problems of Real Estates' Valuation for Taxing Purposes, FIG Working Week 2008, Stockholm, Sweden 14-19 June 2008.

Pagourtzi, E., Assimakopoulos, V., Hatzichristos, T., French, N., 2003, Real Estate Appraisal: a Review of Valuation Methods, Journal of Property Investment \& Finance, Vol. 21, No. 4, pp. 383-401.

PREWEDA E., 2013, Rachunek wyrównawczy $\Rightarrow$ modele statystyczne (Adjustment Computations $\Rightarrow$ Statistical Models), Wydawnictwo PROGRES, Kraków. 
Renigier-BiŁozor, M., BiŁOzor, A., WisnieWski, R., 2017, Rating Engineering of Real Estate Markets as the Condition of Urban Areas Assessment, Land Use Policy, Vol. 61, pp. 511-525.

REJESTR Cen i Wartości Nieruchomości prowadzony przez Urząd Miasta w Krakowie, 15.06.2016 (Register of Real Estate Prices and Values kept by the Kraków City Office, 15.06.2016).

UstAWA z dnia 21 sierpnia 1997 roku o gospodarce nieruchomościami, tekst jednolity z dnia 14 grudnia 2016 roku, Dz. U. z 2016 r. nr 2147, z późn. zm. (Act of 21 August 1997 on Real Estate Management, consolidated text of 14 December 2016, Journal of Laws of 2016, item 2147, as amended).

UstAWA z dnia 27 marca 2003 roku o planowaniu $i$ zagospodarowaniu przestrzennym, tekst jednolity z dnia 11 maja 2017 roku, Dz. U. z 2017 r. nr 1073 (Act of 27 March 2003 on Spatial Planning and Development, consolidated text of 11 May 2017, Journal of Laws of 2017, item 1073).

WIŚNIEWSKI Z., 2005, Rachunek wyrównawczy w geodezji (Compensatory Account in Geodesy), Wydawnictwo Uniwersytetu Warmińsko-Mazurskiego, Olsztyn.

ZYGA J., 2012, Istota podobieństwa w procedurach wyceny nieruchomości (Essence of Similarity in Real Estate Appraisal Procedures), Rzeczoznawca Majątkowy, Vol. 75, No. 3, pp. 22-26.

${ }^{*}$ This study has received financial support from statutory research No. 11.11.150.006. 